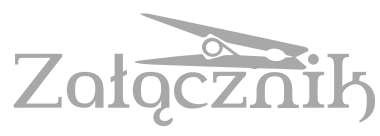

\title{
REFERRING TO REGIONAL DRESS: DUTCH TRADITIONAL COSTUMES AS RECURRING INSPIRATION FOR CONTEMPORARY FASHION DESIGN
}

\author{
MARTA KARGÓL
}

Over the past two decades, both beginner and experienced fashion designers have taken inspiration from traditional Dutch costumes (klederdracht) to create single outfits or entire collections. In the Netherlands, with the exception of some remote villages around the former Zuiderzee and in the province of Zealand, the traditional costumes have disappeared almost completely. Yet, at the local and national levels, the costumes remain an important element of tangible and intangible heritage ${ }^{1}$. A meaningful sartorial tradition, as well as the wealth of colours and patterns that characterises the fabrics, make these ethnic costumes an interesting source of inspiration for designers, particularly in the Netherlands. Traditional Dutch costumes have also attracted attention from foreign fashion creators ${ }^{2}$. The costumes take on a new role in contemporary culture as an inspiration for modern design. In this way, the heritage is preserved in a reflective and creative way for further generations. In addition, Dutch designers use traditional dress as inspiration in order to express their local or national identity. The culture of French fashion has been strongly influencing fashion design in the Netherlands for centuries. This has led to a situation where contemporary designers lack a point of reference in fashion design. Therefore,

${ }^{1}$ M. Kargól, Moda na tradycję. Znaczenie holenderskich strojów regionalnych w różnych kontekstach współczesnej kultury holenderskiej, Poznań 2015.

2 Eadem, Contemporary Fashion. Klederdracht in een nieuwe jas, eds. J. van den Berg, S. Veen, Amsterdam 2018. 
the designers use regional costumes as their source of inspiration to prove that the Netherlands has its own sartorial tradition that boasts unique techniques, patterns, and fabrics ${ }^{3}$.

The aim of this paper is to look closely at various examples of fashion designs derived from traditional dress and analyse their formal and aesthetic attributes. Design analysis should reveal the variable ways in which traditional dress is given a new life while being used as inspiration. The terms used in intertextuality and literary studies have been adopted to paint a clear picture of the different creative ways in which the designers use Dutch costumes in their work. This method is justified because the whole culture, with its various forms of expression, can be sourced within text ${ }^{4}$. The selected examples of designs can be grouped into the following categories: quotation, allusion, paraphrase, pastiche, and translation. Quotation, meaning a repetition of someone else's sentence ${ }^{5}$, can be understood in design as appropriating pieces of clothing, accessories or fabrics. An allusion, which is defined as an expression that recalls another cultural text ${ }^{6}$, occurs in design when some of an object's elements or features are not explicit. In other words, it is a type of inspiration that results in objects whose characteristics are indirect references to a sartorial tradition or the shape or aesthetics of traditional clothing, rather than express appropriations. Paraphrase is defined as a reinterpretation of a meaning of something stated by another person ${ }^{7}$. In case of design, a paraphrase can be repetition of a technique or form in which a strong emphasis was placed on the presence of the individuality and

3 J. Teunissen, De Nederlander bestaat wel, [in:] Gejaagd door de Wind. Zuiderzeemuseum, Enkhuizen 2009; idem, Nederlandse mode en Nederlandse klederdracht: twee kanten van dezelfde medaille, „Land of Water” 2009, Vol. 3, No. 1, p. 80-95; A. Smelik, Delft blue to denim blue, London 2017.

4 G. Machacek, Allusion, „PMLA” 2007, Vol. 122, No. 2, p. 524.

5 R. Sokolowski, Quotation, „The Review of Metaphysics” 1984, Vol. 37, No. 4, p. 699.

6 M. Kuleli, Intertextual allusions and evaluation of their translation in the novel „Silent House” by Orhan Pamuk, „Procedia - Social and Behavioral Sciences” 2014, Vol. 158, p. 206-213.

7 P. Leth, Métaphore et paraphrase, „Archives De Philosophie” 2007, Vol. 70, No. 4, p. 579-598. 
creativity of the designer. The next category is pastiche, which is a humorous way to refer to another text or image ${ }^{8}$. Last but not least, another way of using traditional dress can be called translation". Translation is understood as communication in another language or meaning taken from a cultural text. With reference to design, several languages, in which a designer expresses himself and makes his outfit unique, can be distinguished. These languages are: textile manufacturing techniques, fabrics, colours, the cut of clothing, and decorative design. Translation in design occurs when an element of one of these languages is used to inspire something else in another; for example, a technique that inspires a decorative motif.

This type of classification leads to the question of the distance between the object being designed and its inspiration source. Therefore, I will reflect on the question: To what extent is the source of inspiration of the designs based on Dutch traditional dress recognisable, and to whom?

\section{DESIGNERS AND THEIR PROJECTS}

A general distinction within fashion and textile designs inspired by Dutch traditional dress can be made based on whether they were created by an individual or as part of a collective project. Some designers decided to use Dutch sartorial traditions as their inspiration individually. Among them were Viktor \& Rolf (Viktor Horsting [b. 1969] and Rolf Snoeren [b. 1969]) ${ }^{10}$. In 2007, this world-famous fashion duo created an entire winter collection $2007 / 2008^{11}$ inspired by regional dress. The young fashion designer Tess van Zalinge (b. 1989) ${ }^{12}$ chose instead only one specific garment to work with when designing his 2018 collection titled Maandag-Wasdag, which means 'Monday Laundry Day'. Additionally, two foreign fashion designers took inspiration from the traditional dress and fabrics from the Dutch village

8 M. Fletcher Reading Revelation as Pastiche: Imitating the Past, London 2017, p. 51-59.

9 W. Bishop, D. Starkay, Translation, [in:] Keywords in Creative Writing, Boulder (CO) 2006, p. 186-190.

10 See: http://www.viktor-rolf.com/ [accessed: 20.10.2019].

${ }^{11}$ See: https://www.vogue.com/fashion-shows/fall-2007-ready-to-wear/viktor -rolf/slideshow/collection\#1 [accessed: 20.10.2019].

12 See: https://www.tessvanzalinge.com/ [accessed: 20.10.2019]. 


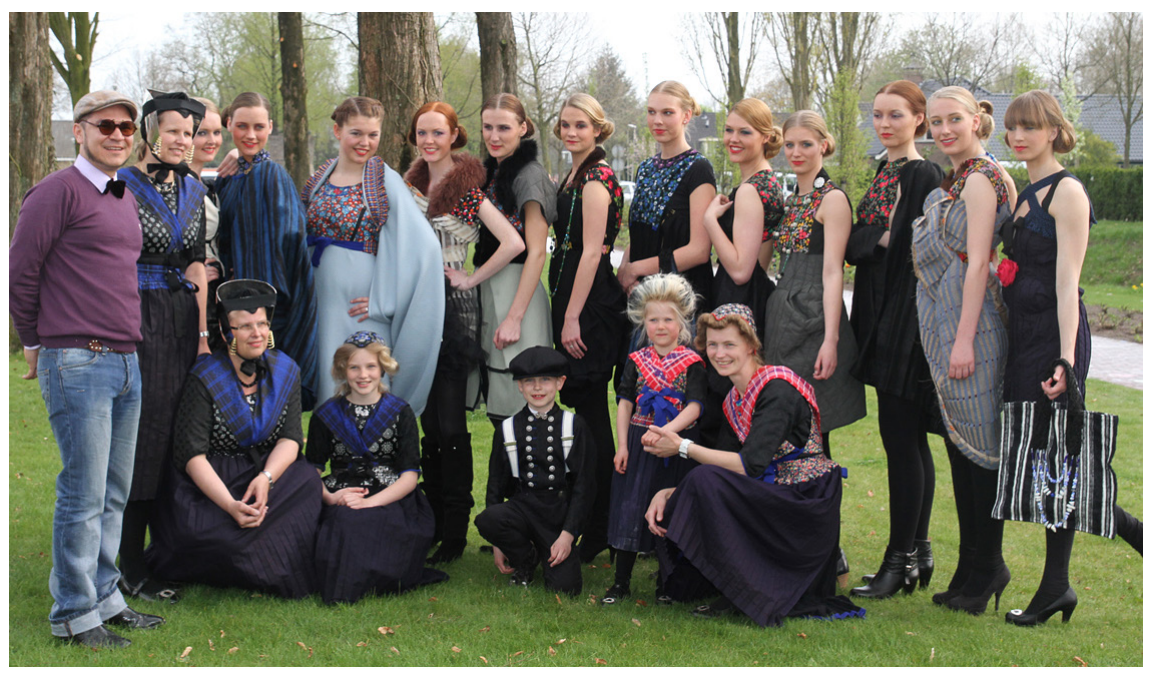

Fig. 1. Ricardo Ramos, Reconstructing Klederdracht, 2009 (photography: Andres Rodriguez)

of Staphorst. One of them was a Columbian-Spanish designer (fig. 1), Ricardo Ramos (b. 1972) ${ }^{13}$, who in 2009 created the collection called Reconstructing Klederdracht ('Reconstructing Traditional Costumes'). The other one was Belgian designer Walter van Beirendonck (b.1957) ${ }^{14}$, who, in his collection called Why is a Raven like a Writing-desk? (2017), introduced a traditional technique of fabric decoration called stipwerk. Stipwerk is a unique technique of handmade decoration, primarily used in Staphorst, where it holds an important status as a part of the local intangible heritage. The technique's name can be translated as 'dot-work', which accurately describes its nature: flowers, stars, and abstract motifs created from small dots ${ }^{15}$. The designers carried out their individual research, collected traditional fabrics, and learned about techniques and traditional dress meanings before incorporating them into their outfits.

A museum project was another way of using traditional clothing as inspiration by some designers. Over the past two decades, a number of museums

13 See: https://www.notjustalabel.com/ricardo-ramos [accessed: 20.10.2019].

14 See: http://www.waltervanbeirendonck.com/ [accessed: 20.10.2019].

15 For more information, see: D. Kok, Kleurrijk gedrukt: oorsprong en ontwikkeling van het Staphorster stipwerk, Kampen 2014. 
in the Netherlands has been trying a strategy of exhibiting historical artefacts from their collections alongside modern designs based on the same or similar objects. These projects' concepts have changed. While at the beginning of this century the material aspects of traditional costumes would inspire the designers, some recent projects focused more on techniques and craftsman-

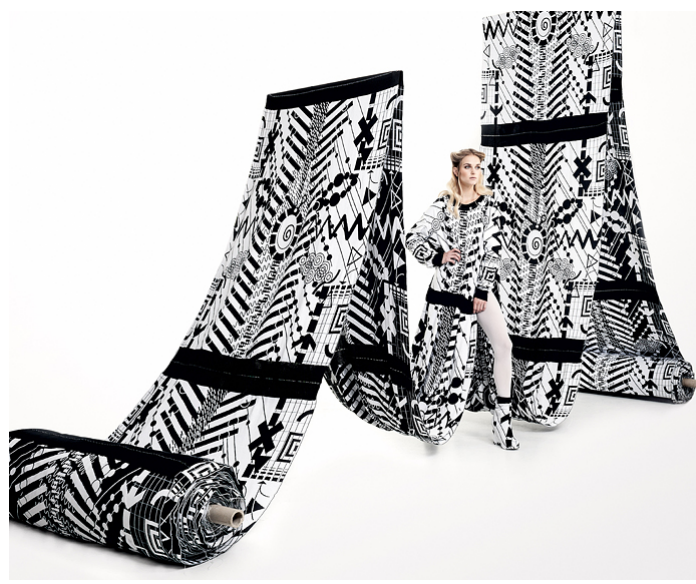

Fig. 2. Handwerk Meesterstuk Antoine Peters, Zeeuws Museum (photography: Marc Deurloo)

ship. This shows that more attention is gradually being paid to intangible heritage. Two designers, whose work will be discussed in this essay, were involved in this kind of project. Antoine Peters (b. 1981) ${ }^{16}$ took part in the exhibition Handwerk ('Handicraft') organised in 2014 by Het Zeeuws Museum in Middelburg ${ }^{17}$ (fig. 2). Bas Kosters (b. 1977) ${ }^{18}$ was involved in a project organised by Het Zuiderzeemuseum in Enkhuizen ${ }^{19}$ and the association Textiel Factorij ${ }^{20}$. Outfits, which were created during this project, became part of Kosters' collection My Paper Crown and some were put on display during the exhibition Ambacht in dracht ('Craftmanship in Traditional Costumes') organised by the museum in 2018.

16 See: http://www.antoinepeters.com [accessed: 20.10.2019].

17 See: https://www.zeeuwsmuseum.nl/nl/over-het-museum/publicaties/ handwerk-handboek [accessed: 20.10.2019].

18 See: https://www.baskosters.com/ [accessed: 20.10.2019].

19 See: http://www.textielfactorij.org/persbericht-ambacht-dracht-het-zuiderzeemuseum/ [accessed: 20.10.2019].

20 See: https://www.textielfactorij.org/profile/baskosters/ [accessed: 20.10.2019]. 


\section{QUOTATION}

Quotation is not simply repetition, it is the repetition of a statement made by somebody else. In the case of a literary text, the words are exactly the same, but the meaning is different, which can be described as follows: 'We see an object, but the object is reflected in the mirror'21. This mirror consists of the creativity of the author and the way they introduce the quotation in their own work. Quotation is also a manifestation. It can include different statements, such as identification with a source or appreciation of it. Therefore, quotation, is not only the repetition of representation, but also it involves what the representation actually says; the range of meanings multiplies. In addition, using the someone else's statement can reinforce a new message. As mentioned earlier, quotation in design occurs when a piece of clothing, a particular form or fabric is appropriated and used exactly as traditional communities have worn or used it. Textile manufacturing techniques, which are used in exactly the same way as in the past, can also be considered a quotation. Moreover, it should be pointed out that the message of traditional dress and textiles is contained not only in their original uses and symbolism, but also in new connotations that they gain while becoming a heritage or entering popular culture. When quoting a piece of text, we are obliged to refer to the original source. In case of fashion design, it can be a project title or a collection that becomes a reference.

Ricardo Ramos, the Spanish-Columbian designer of women's fashion, is fascinated by ethnic clothing all over the world and the way it expresses identity ${ }^{22}$. He uses and reuses whole pieces or elements of traditional costumes, fabrics, and adornments. In 2009, when the designer was working on his collection Reconstructing Traditional Costumes ${ }^{23}$, several hundred women in the village of Staphorst still wore local traditional costumes as daily dress $^{24}$. This cultural aspect was very important to the designer. However,

${ }^{21}$ R. Sokolowski, op. cit., p. 699.

22 Based on interview with Ricardo Ramos, January 2013.

23 See: http://www.staphorstinbeeld.nl/index.php/11-kunst/84-ricardo-ramos [accessed: 20.10.2019].

${ }^{24}$ M. Kargól, „Staphorst na wybiegu”. Inspiracja tradycyjnymi strojami holenderskimi w modzie współczesnej jako forma obcowania z lokalną tradycją, „Rocznik Antropologii Historii” 2013, Vol. 2, p. 279. 
he was also fascinated by the specific fabrics, colours, patterns, techniques of decoration, and the cut of the clothing. Ramos visited the village several times in order to gather the necessary information and to collect the objects and fabrics. Thereafter, he used them to create his whole collection ${ }^{25}$. His inspiration from traditional dress is versatile and all-inclusive. The fabrics, the forms and even individual pieces of dress, like head coverings and so-called kraplap, are 'literally' included in his outfits. Kraplap was worn in different places and regions in the Netherlands. It was a piece of fabric with a head opening that covered the upper part of the body ${ }^{26}$. Kraplap is a distinct form of quotation in the collection. Furthermore, Ramos quotes the combination of colours that dominated in the traditional dress: black and different shades of blue. Besides, he made the black stockings and black shoes, that were worn by women in Staphorst, inseparable elements of all his outfits. These shoes, as well as the stockings, are very characteristic of the local dress from Staphorst, but they are also a recognisable sign of belonging to the very traditional Protestant communities in the Netherlands ${ }^{27}$. By using them, Ramos does not only quote the colours or types of clothing. He also refers to cultural meanings hidden in them. As the definition of quotation states, one quotes not to repeat the exact meaning but to emphasise or express one's own statement. Ramos was fascinated by the fact that women in Staphorst still wore traditional dress in daily life. In that context, this quotation can be interpreted as homage given to the attitude of preservation the local traditions.

\section{ALLUSION}

Allusion is defined as phraseological adaptation ${ }^{28}$. The term allusion is juxtaposed with such terms as influence or imitation, which have rather negative connotations. Intertextuality is about bringing in different influences which

${ }_{25}$ Staphorst op de catwalk. Klederdracht uit de mode in de mode, Staphorst 2012, p. 202-211.

${ }^{26}$ C. Nieuwhoff, W. Diepraam, C. Oorthuys, The costumes of Holland, Amsterdam - Brussels 1985, p. 37-43, J. Rozenbroek, C. Oorthuys, Klederdrachten. De schoonheid van ons land, Amsterdam - Antwerpen 2008, p. 42-44.

${ }^{27}$ Staphorst op de catwalk..., op. cit., p. 24.

28 G. Machacek, op. cit., p. 522. 
are anonymous, but somehow familiar ${ }^{29}$. When designers decide to quote or make allusion, they do not do it because of a lack of their own creativity. Their creativity is demonstrated by the innovative ways in which they adapt the original. Therefore, the primary source and the new creations can be considered equal ${ }^{30}$.

Bas Kosters based his collection from 2017, called Paper Crown ${ }^{31}$, on several sources, such as rococo, African traditional dress, and the fisherman's costume worn in the region of the former Zuiderzee (fig. 3). Organised by Textiel Factorij and Het Zuiderzeemuseum in Enkhuizen, the project was meant to bring together Dutch designers and artisans from India and thus connect heritage of two continents. The aim of the project was to create modern designs using traditional techniques of textile production and sartorial practises. The designers created new patterns for Chintz fabrics which were printed by the Indian artisans in a traditional way ${ }^{32}$. Kosters himself designed new patterns for fabrics which were then used to make his outfits. The cut of these outfits was based on the traditional fisherman's costume worn in the past in the Netherlands. Metal coins, which in Koster's designs serve as buttons, can be seen as quotations, because this was customary in the past. Throughout his collection, Kosters refers to various sources and meanings. However, the source of inspiration is not as strongly present in his designs as it is in the outfits created by Ricardo Ramos. As the definition of allusion states, knowledge about fabrics, as well as sartorial traditions, are required. The combination of so many different influences prove the originality of these designs and the high level of creativity achieved by Kosters.

The title of Tess van Zalinge's collection Monday Laundry Day refers to the fact that, in the past, it was a custom to do the weekly laundry on

29 S. Ross, Art and Allusion, „The Journal of Aesthetics and Art Criticism” 1981, Vol. 40, No. 1, p. 60-61.

30 G. Machacek, op. cit., p. 525.

31 See: https://www.instagram.com/explore/tags/mypapercrown/ [accessed: 20.10.2019].

32 For more information about the chintz textiles see: G. Arnolli, J. Dijkstra, E. Hartkamp-Jonxis, R. Reddy and M. Stoter, Sits, katoen in bloei: sitsen uit de collectie van het Fries Museum, Leeuwarden 2017. 
Mondays. The white, delicate and often transparent outfits are an allusion to underwear made of white linen, the part of wardrobe that had to be washed most often. In her designs, van Zalinge also alludes to kraplap, the part of the traditional outfit mentioned earlier. The most characteristic kraplap was worn in the village of Spakenburg where it was starched and had the biggest size. The kraplap from Spakenburg appears as allusion in the designs of van Zalinge, but it is smaller and delicate; only its rather geometrical form recalls the traditional piece of dress from that region. What is more, the white, subtle fabrics she uses also refer to the sartorial history: the female underwear, which

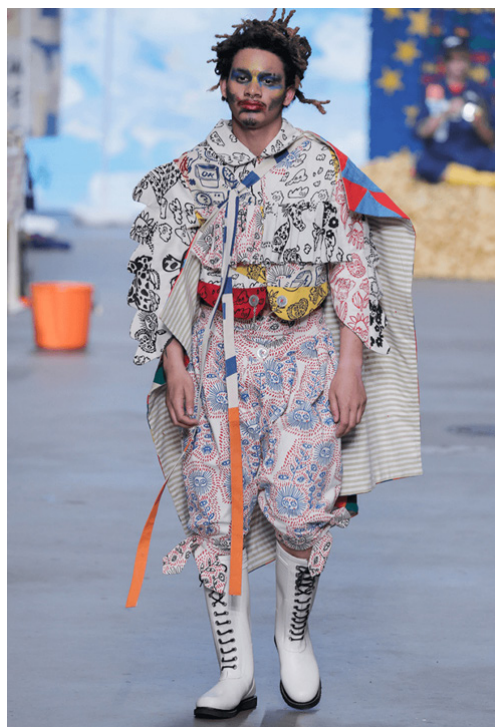

Fig. 3. Bas Kosters Studio for Ambacht in dracht (photography: Team Peter Stigter) was partly visible in the from under the outfit, for example in the neckline. In this sense, the way van Zalinge used two inspirations and merged them into one design, without making them overly explicit, is an example of allusion.

\section{PARAPHRASE}

The most basic example of paraphrase is the alteration of a sentence or some part of it into another grammatical form. While paraphrase sometimes has negative connotations, its value lies in the sentence's clarification or improvement. Applying the definition of paraphrase to design, it can be said that a paraphrase is the transformation of a shape, colours or design. It does not improve the original objects, which play the role of the inspiration source, but rather, it strengthens the expression of the new design.

Viktor \& Rolf, the Dutch fashion duo, create extravagant, experimental, and conceptual outfits. The outfits they create are seen more as pieces of art than items of fashion. Their collection for winter 2007/2008 was inspired by Dutch national costumes. Viktor \& Rolf used fabrics characteristic of regional dress, with recognisable patterns and colours. All the outfits belonging to this 


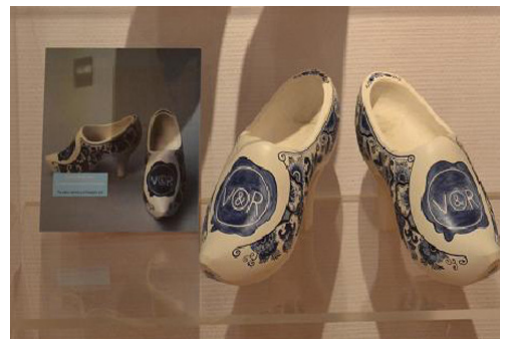

Fig. 4. Viktor \& Rolf, Shoes, Klompenmuseum in Eelde (photography: Marta Kargól) collection included high-heeled shoes based on traditional clogs and made according to historical craftmanship (fig. 4). The shoes were made of wood and were grooved and decorated with different patterns, some of which exactly repeat the motifs used in the past as decoration for clogs. The way traditional shoes were used by Viktor \& Rolf is quite close to quotation, as the clogs are almost literally appropriated. However, the heels are an addition that changes the quotation into a paraphrase. A paraphrase may accompany an exact quotation, but it does not have to. It puts a message from the original source into a new perspective, expressed in a slightly different way. This is what happens with the clogs in the context of the whole outfit or, to an even greater extent, in the whole collection. The Dutch regional heritage is the source of inspiration, and contemporary fashion design is the perspective. In addition, all the shoes were marked with the logo of the designers, 'V\&R'. The designers made themselves explicitly visible, as if they wanted to point out that they were rewriting a quotation in their own style. The motifs used as decoration for shoes by Viktor \& Rolf are not always taken from traditional clogs, but also from clogs-souvenirs. The clogs-souvenirs are, for example, decorated with the blue decorations which are characteristic for the pottery from Delft. This is a very interesting case in the context of this analysis, as the designers made a paraphrase of the popular culture motif, which itself is a paraphrase of the objects from traditional culture.

\section{PASTICHE}

Pastiche can be used to describe the way the Belgian designer Walter van Beirendonck uses Dutch traditional dress as inspiration. Two characteristics of pastiche should be emphasised before starting the analysis: an exaggerated emphasis on some of the original features and a humorous style. It is also important to note that the author's intention is not to ridicule the source, but rather to make a gesture of admiration. 
The title of van Beirendonck's collection, Why is a Raven like a Writing-desk? ${ }^{23}$, is taken from a famous riddle from the children's book Alice in Wonderland. Because of the variations of fabrics and colours, unexpected shapes, and wonderful details, his creations are very versatile. In this collection, Van Beirendonck includes the previously mentioned

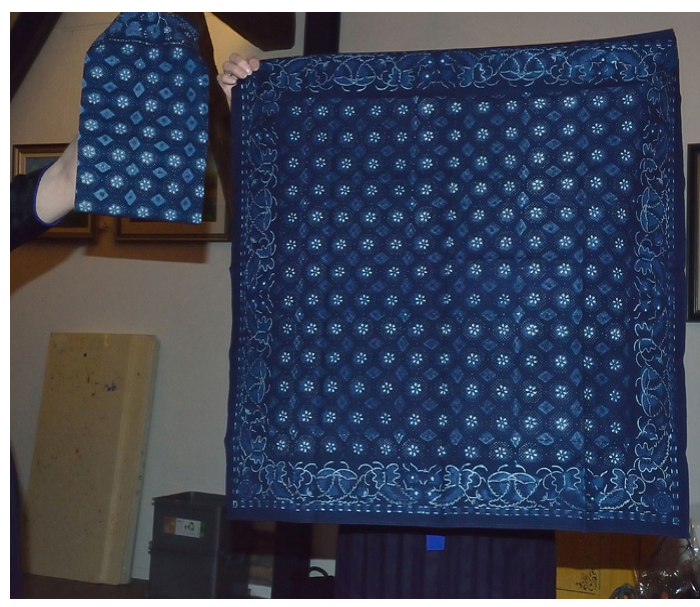

Fig. 5. Staphorster Stipwerk, 2016 (photography: Rasbak) stipwerk. The fabrics used by van Beirendonck were made by Gerard van Oosten, a craftsman from the village of Staphorst (fig. 5). Van Oosten covered the Belgian designer's fabrics with the same dots, with some often being bigger in places. This makes the design less subtle. The first characteristic of the pastiche finds its expression right here. Moreover, the designer added some extra motifs, like emoticons with smiles. The technique is original, and it is even produced by a local maker. The style of the design is the same but the additional motifs bring another layer of meaning. Van Beirendonck repeats in his own words what has already been said. By doing so, he emphasises his own presence as a designer. Therefore, this way of using other objects as inspiration could be called a paraphrase. However, it can also be seen as a pastiche, considering the humorous nature of the motifs. The traditional technique is not mocked by Van Beirendonck. Rather, his imitation is a gesture of admiration towards it and celebration of it.

33 See: http://www.waltervanbeirendonck.com/HTML/home.html?/HTML/ COLLECTIONS/SS2017/public.html\&1 [accessed: 20.09.2019]. 


\section{TRANSLATION}

Translation is a form of inspiration in which the newly created object appears to be the farthest from the original. An object that inspires an artist or designer can be incomprehensible or completely unrecognisable in the resulting creation. The way in which this inspiration is used remains unclear as well. This occurs because the language is different. When traditional dress is used as inspiration for contemporary projects in order to express the designer's identity or an attitude toward heritage, it is important that the inspiration remains obvious and easily readable. Therefore, translation as a way of working with this particular source of inspiration does not occur that often. However, the source of inspiration may be clear when it is included in the context of a larger project, for example initiated by a museum.

The exhibition Handwork from 2014, organised by Het Zeeuws Museum in Middelburg, is an excellent example of such case. The exhibition was focused, as the title itself suggests, on promoting traditional $\mathrm{crafts}^{34}$. A number of invited designers were asked to select an object from the museum's collection and examine the technique used to create it. Peters decided to use traditional costumes from the province of Zealand, especially a piece of dress called the $j a k^{35}$. The jak was a female outfit that can be compared to a jacket. The jak was not cut from a pattern, but it was literally pleated from two overlapping pieces of fabrics. The excess fabric was folded and stitched together. The upper and inner parts of this outfit present a complicated network of folds and stiches ${ }^{36}$. It took a lot of skill and detailed knowledge of this technique to make such a jacket. Peters' task was to discover the principles of the technique with which the jacket was made and understand them; he had to learn a specific language, the language of traditional crafts, which was, additionally, not written down. The ability to construct this outfit was a component of a traditional craftsperson's specific skills, passed from generation to generation. Peters had a museum facility at his disposal, which means he was allowed to use the museum object for his research; that is, he could interfere with the outfit's structure and unravel and develop the folds. He also had the opportunity to work with Madam Vos, a woman

\footnotetext{
${ }^{34}$ Handwerk Handboek, ed. K. Leijnse, Middelburg 2017, p. 9-11.

35 See: https://www.youtube.com/watch?v=jqLJ97laflg [accessed: 20.10.2019].

36 Handwerk Handboek, op. cit., p. 14.
} 
from Zealand, who was still wearing a traditional outfit and who also had a great knowledge of local fabrics and clothing ${ }^{37}$. The designer could take his inspiration literally and make a dress using the same technique, but instead he decided to translate the technique into a motif. Peters translated the complicated network of folding and stitching lines into abstract black and white forms, lines and zigzags. Then he used this motif as a decoration for the knitwear fabric. Peters also made a sweater from the fabric, called the jak-trui (jak-sweater) $)^{38}$. The source of inspiration is not recognisable without knowledge of the context of the design creation.

\section{CONCLUSIONS}

The analysis of the selected designs shows that traditional costumes can become an inspiration in different dimensions. Firstly, designers look at the materiality of dress, which includes the types and form of outfits, aesthetics, and fabrics. Secondly, they are interested in intangible aspects of the dress. The latter can be divided into two further categories. Traditional techniques of textile manufacturing belong to the first category. The second category is the meaning that dress once carried in its traditional context of everyday life; for example, communicating a religious affiliation. Finally, traditional costumes belonging to local and regional cultures underwent the same nationalisation and folklorisation process as other elements of heritage. This way, the costumes also entered popular culture. The most well-known example of this is wooden clogs, which are icons of Dutch national culture. As such, they function as souvenirs and are also easily recognised by foreigners. All these categories reveal the ways in which traditional costumes are present in the contemporary culture.

What applies to the distance between the sources and the designs, quotations, paraphrases, and pastiches are those inspiration strategies that result in new outfits where traditional sartorial traditions can be recognised relatively easily. Allusion is the strategy which can be placed in the middle. When it comes to translation, the greatest distance between the design and its source occurs. To recognise the inspiration, some level of knowledge is

37 Ibidem, p. 14-31.

38 See: http://www.antoinepeters.com/Antoine-Peters-Zeeuws-Museum [accessed: 20.10.2019]. 
needed in all the strategies. The quotation, however, seems to be the easiest to recognise, as the source gets a reference in the title form. Still, the title only indicates that some traditional costumes were the basis for the collection. Even for Dutch people not all the meanings may be easy to recognise, as such recognition requires knowledge and a passion for tradition and the history of dress and fabrics. It becomes even more difficult for foreigners who are not familiar with Dutch regional heritage. The exception is the Viktor \& Rolf paraphrase, which can be recognised not only in The Netherlands, but also abroad. However, this has more to do with the character of the source of inspiration, which belongs to the popular culture, than with the real distance between the source and the contemporary design. Viktor \& Rolf made a statement about national identity ${ }^{39}$, thus, it was important for them to make the audience understand their intentions. In other cases, using traditional dress for inspiration was not necessarily a matter of creating a specific message. Another reason for using Dutch traditional dress was to create a new aesthetic quality. All the designers, whether or not they wanted to renew or promote the heritage of Dutch regional costumes, gave them a new life in the contemporary culture in their creative way.

\section{Bibliography}

Gieneke Arnolli, Julia Dijkstra, Ebeltje Hartkamp-Jonxis, Renuka Reddy, Marlies Stoter, Sits, katoen in bloei: sitsen uit de collectie van het Fries Museum, Fries Museum, Leeuwarden 2017.

Wendy Bishop, David Starkay, Translation, [in:] Keywords in Creative Writing, University Press of Colorado, Boulder (CO) 2006.

Hilde Cammel, Anton Kos, Museale activiteiten, „Land of Water” 2007, Vol. 1, No. 3. Michelle Fletcher, Reading Revelation as Pastiche: Imitating the Past, Bloomsbury Publishing, London 2017.

Handwerk Handboek, ed. K. Leijnse, Zeeuws Museum, Middelburg 2017.

Marta Kargól, „Staphorst na wybiegu”. Inspiracja tradycyjnymi strojami holenderskimi w modzie współczesnej jako forma obcowania z lokalna tradycją, „Rocznik Antropologii Historii” 2013, Vol. 2.

39 H. Cammel, A. Kos, Museale activiteiten, „Land of Water” 2007, Vol. 1, No. 3. 
Marta Kargól, Contemporary Fashion. Klederdracht in een nieuwe jas, eds. J. van den Berg, S. Veen, Het Klederdrachtmuseum, Amsterdam 2018.

Marta Kargól, Moda na tradycję. Znaczenie holenderskich strojów regionalnych w różnych kontekstach współczesnej kultury holenderskiej, Werkwinkel, Poznań 2015.

Dirk Kok, Kleurrijk gedrukt: oorsprong en ontwikkeling van het Staphorster stipwerk, LK mediasupport, Kampen 2014.

Mesut Kuleli, Intertextual allusions and evaluation of their translation in the novel „Silent House” by Orhan Pamuk, „Procedia - Social and Behavioral Sciences” 2014, Vol. 158.

Palle Leth, Métaphore et paraphrase, „Archives De Philosophie” 2007, Vol. 70, No. 4. Gregory Machacek, Allusion, „PMLA” 2007, Vol. 122, No. 2.

Constance Nieuwhoff, Willem Diepraam, Cas Oorthuys, The costumes of Holland, Elsevier, Amsterdam - Brussels 1985.

Anneke Smelik, Delft blue to denim blue, Bloomsbury Publishing, London 2017.

Jose Teunissen, De Nederlander bestaat wel, [in:] Gejaagd door de Wind, Zuiderzeemuseum, Enkhuizen 2009.

Jose Teunissen, Nederlandse mode en Nederlandse klederdracht: twee kanten van dezelfde medaille, „Land of Water” 2009, Vol. 3, No. 1.

Stephanie Ross, Art and Allusion, „The Journal of Aesthetics and Art Criticism” 1981, Vol. 40, No. 1.

José Rozenbroek, Cas Oorthuys, Klederdrachten. De schoonheid van ons land, Contact, Amsterdam - Antwerpen 2008.

Robert Sokolowski, Quotation, „The Review of Metaphysics” 1984, Vol. 37, No. 4. Staphorst op de catwalk. Klederdracht uit de mode in de mode, LK mediasupport, Staphorst 2012.

\section{Online sources}

http://www.antoinepeters.com.

http://www.antoinepeters.com/Antoine-Peters-Zeeuws-Museum.

http://www.staphorstinbeeld.nl/index.php/11-kunst/84-ricardo-ramos.

http://www.textielfactorij.org/persbericht-ambacht-dracht-het-zuiderzeemuseum/. http://www.viktor-rolf.com/.

http://www.waltervanbeirendonck.com/.

http://www.waltervanbeirendonck.com/HTML/home.html?/HTML/ COLLECTIONS/SS2017/public.html\&1. 
https://www.baskosters.com/.

https://www.instagram.com/explore/tags/mypapercrown/.

https://www.notjustalabel.com/ricardo-ramos.

https://www.tessvanzalinge.com/.

https://www.textielfactorij.org/profile/baskosters/.

https://www.vogue.com/fashion-shows/fall-2007-ready-to-wear/viktor-rolf/ slideshow/collection\#1.

https://www.youtube.com/watch?v=jqLJ97laflg.

https://www.zeeuwsmuseum.nl/nl/over-het-museum/publicaties/hand werk-handboek.

\section{Referring to Regional Dress: Dutch Traditional Costumes as Recurring Inspiration for Contemporary Fashion Design}

In this article, the author aims to classify and analyze the use of Dutch regional costumes as a source of inspiration by contemporary fashion designers. The strategies have been assigned the following concepts taken from literary (and cultural) studies: quote, allusion, paraphrase, pastiche and translation. The definitions of these concepts are used as tools for interpreting the ways in which Dutch regional costumes are made present by fashion designers in their outfits. The article discusses the role of distance and similarities between the source of inspiration and its interpretation in the contemporary fashion design.

Keywords: Dutch regional costumes, contemporary fashion, craft, inspiration, interpretation 